\title{
Peranan Pemimpin Gereja Dalam Memperlengkapi Jemaat Bagi Pertumbuhan Gereja
}

\section{Yunus Selan}

Sekolah Tinggi Teologi Pelita Dunia, Tangerang

masyiah@hotmail.com

\begin{abstract}
This study discusses the Role of Church Leaders in Equipping the Congregation for Church Growth. Researchers used qualitative methods, researchers found the conclusion that the role of church leaders is very significant for the growth of congregation faith.
\end{abstract}

Keywords: Leader, Congregation and Church Growth

Abstrak: Penelitian ini membahas tentang Peranan Pemimpin Gereja Memperlengkapi Jemaat Bagi Pertumbuhan Gereja. Peneliti menggunakan metode kualitatif, peneliti menemukan kesimpulan bahwa peran pemimpin gereja sangat signifikan bagi pertumbuhan iman jemaat.

Kata Kunci: Pemimpin, Jemaat dan Pertumbuhan Gereja

\section{Pendahuluan}

Pembahasan tentang pengertian pemimpin gereja, meliputi; pemimpin secara umum dan pemimpin gereja yaitu pemimpin gereja menurut Perjanjian Lama dan pemimpin gereja menurut Perjanjian Baru.

Secara etimologi pemimpin berasal dari bahasa Inggris yaitu "dari kata 'to lead' yang berarti pemimpin. Kemudian berubah menjadi 'leader' yang berarti pemimpin dan 'leadership' yang berarti kepemimpinan"1. Sedangkan menurut kamus lengkap bahasa Indonesia modern, "Pemimpin adalah orang yang memimpin"2. Sedangkan Kamus Besar Bahasa Indonesia, "Pengertian pemimpin adalah orang yang memimpin; ia ditunjuk untuk memimpin". ${ }^{3}$

Jadi pemimpin adalah orang yang menerima otoritas dalam sebuah organisasi dan untuk mencapai tujuan organisasi tersebut tergantung pada kualitas pemimpin. Menurut J. Oswald Saners; "pemimpin adalah orang yang mengenal jalan yang dapat terus maju dan dapat menarik orang lain mengikuti

${ }^{1}$ A.M. Mangunhardjana, Kepemimpinan, (Yogyakarta: Kanasius, 1976) hlm. 11

2 Muhammad Ali, Kamus Lengkap Bahasa Indonesia Modern, (Jakarta: Pustaka Amani, t.th.) hlm 229

3 Tim penyusun Kamus Besar Bahasa Indonesia, (Jakarta; Balai Pustaka 2001) hlm. 874. 
dia"4. Pemimpin sebagai pribadi yang dipercaya untuk bertanggung jawab dalam suatu organisasi haruslah orang sudah mengenal jalan menuju tujuan yang hendak dicapai. Cara yang dipakainya ialah kemampuannya untuk mempengaruhi orang-orang yang dipimpinnya dalam mencapai tujuan bersama.

Memimpin merupakan salah satu kebutuhan yang asasi manusia, sehingga diperlukan dari urusan rumah tangga sampai memimpin bangsa dan Negara. Mengenai upaya menjadi pemimpin Evendhy M. Siregar mengatakan;

"untuk menjadi pemimpin yang berkualitas perlu usaha yang tidak ringan, terus menerus menggembleng diri, sehingga dapat mencapai beberapa persyaratan, diantarannya punya wawasan luas, sehingga cepat beradeptasi dengan lingkungan dan permasalahan, tidak boleh cepat kaget, terheranheran atau gugup, mampu memelihara ketenangan dalam mengatasi komplikasi situasi. Selain itu pemimpin harus mampu menganalisa kecenderungan perkembangan situasi, melihat criteria points, mengembangkan berbagai alternative pemecahan dan memilih satu yang terbaik, serta menjabarkannya dalam tindakkan nyata"5.

Dengan demikian maka pemimpin adalah orang yang teruji kualitas dan kompetensinya, integritasnya dalam mengatur, mengarahkan perkembangkan organisasi yang dipimpinnya. Karena itu pemimpin yang berkualitas harus selalu belajar dan berlatih, untuk menemukan metode-metode baru dalam mengarahkan orang-orang yang dipimpinnya untuk mencapai tujuan bersama dalam organisasi.

Pemimpin dalam kepemimpinannya Yakob Tomatala mengatakan; "Kepemimpinan ialah seni bekerja (tahu, mau, aktif bekerja) bersama melalui orang lain. Defenisi ini menekankan kemampuan dan ketrampilan yang harus ada pada seorang pemimpin untuk dapat bekerja dan mampu bekerja sama dengan orang lain.6" Pemimpin harus orang tahu bekerja, mau bekerja dan aktif bekerja dan mampu bekerja sama dengan orang-orang yang dipimpinnya. Orientasinya mengarahkan kepada relasi antara pemimpin dengan bawahan dan bawahan dengan pekerjaannya. Pemimpin juga bertanggung jawab memenuhi kebutuhan para bawahannya. Dalam hal ini pemimpin tidak akan berhasil jika tidak mampu bekerja sama dengan bawahannya. Karena itu di

${ }^{4}$ J.Oswald Saners, Kepemimpinan Rohani (Bandung: Yayasan Kalam Hidup, 2001) hlm 20.

${ }^{5}$ Evendhy M. Siregar, Bagaimana Menjadi Pemimpin Yang Berhasil, (Jakarta; 1998) hlm 54-55.

${ }^{6}$ Yakob Tomatala, Kepemimpinan yang dinamis, (Jakarta: Leadership Foundation, 1997), hlm. 32 . 
dalam hubungan pemimpin dan bawahan perlu adanya suatu aturan yang mengikat lewat garis otoritas di dalam organisasi.

Inti kepemimpinan adalah fungsi atau tugas yang terarah pada tujuan yang hendak dicapai demi kesejahteraan kehidupan orang banyak. Tentang timbulnya bakat kepemimpinan seseorang Agus Lay mengatakan bahwa;

(a). Teori genetis yang menyatakan bahwa seorang menjadi pemimpin oleh karena memang dilahirkan dengan bakat kepemimpinan. (b). Teori social yang menyatakan bahwa setiap orang dapat menjadi pemimpin kalau dia memperoleh pendidikan dan pengalaman. (c). Teori ekologis, memakai teori genetis dan teori social"7.

Maksudnya bahwa ada tiga teori dasar tentang kepemimpinan seorang pemimpin yaitu; Teori genetis artinya seorang pemimpin memiliki bakat kepemimpinan sejak lahir. Hal ini mungkin karena factor keturunan atau karunia khusus dari Tuhan; teori social artinya kepemimpinan seorang pemimpin diperolehnya melalui pendidikan dan pengalaman yang memadai; sedangkan teori ekologis artinya kepemimpinan seorang pemimpin yang diperolehnya karena factor genetic dan social. Pada dasarnya manusia punya kemampuan untuk memimpin, namun ilmu pengetahuan sangat penting peranannya untuk mengembangkan potensi manusia agar menjadi lebih efektif dan efesien.

\section{Metode Penelitian}

Pada penelitian ini, penulis atau peneliti menggunakan pendekatan atau metode kualitatif untuk memperoleh data yang valid guna membangun sebuah teori yang berkaitan dengan tema atau pokok penelitian. Metode kualitatif yang dimaksud adalah mengkaji dan mengelaborasi setiap sumber, informasi dan data-data yang diperoleh dari pustaka.

\section{Hasil dan Pembahasan}

\section{Pengertian Pemimpin Gereja}

Seorang pemimpin gereja tidak sama dengan seorang pemimpin secular di perusahaan atau organisasi lainnya. Karena cara kerjanya berbeda, pekerjaannya berbeda dan tujuannyapun berbeda. Kepemimpinan Kristen memiliki keunikan tersendiri bila ditinjau dari hakekatnya yang teosentris. Untuk memahami kepemimpin gereja, maka Yakob Tomala mengatakan; Kepemimpinan gereja adalah suatu proses terrencana yang dinamis dalam

${ }^{7}$ Agus Lay, Manajemen Pelayanan, (Malang: Lembaga Pelayanan Mahasiswa Indonesia, 1998) hlm 30 
konteks pelayanan Kristen yang didalamnya oleh campur tangan Allah. Ia memanggil bagi diriNya seorang pemimpin untuk memimpin umatNya guna mencapai tujuan Allah bagi dan melalui umatNya, untuk kejayaan

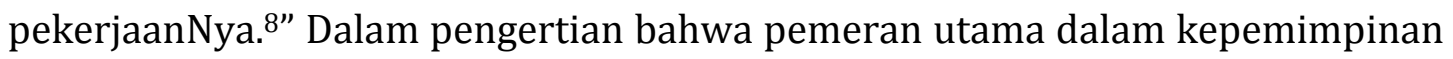
gereja adalah Allah sendiri yang berinisiatif dalam seluruh proses yang terrencana dan dinamis. Jadi dalam kepemimpinan Kristen pemimpin hanya sebagai alat yang dipakai Allah untuk menata pelayanan Allah dan menyampaikan kehendak Allah kepada umatNya. Adapun perbedaan yang sangat hakiki adalah pemimpin secular sebagai penguasa dalam kepemimpinannya, sedangkan pemimpin gereja sebagai pelayan dalam kepemimpinannya.

Mengenai pemimpin gereja sebagai pelayan, maka Christ Marantika mengatakan bahwa; "Kepemimpinan gereja adalah seseorang yang menjadi pemimpin dari antara sekian banyak orang Kristen, dengan tujuan untuk mempermuliakan nama Tuhan di dunia ini, baik melalui kesaksian hidup seharihari, maupun dengan persekutuan" ${ }^{\prime}$. Artinya seorang pemimpin gereja dipenuhi Roh Kudus, yang berjalan dalam iman dan membawa orang lain menyerahkan dirinya kepada Kristus dan bertindak dalam kuasaNya. Karena itu seorang pemimpin gereja memiliki kerinduan besar untuk menggenapi Amanat Agung Tuhan Yesus Kristus, serta memimpin orang lain untuk terlibat didalamnya.

Christ Marantika mengatakan; "Kehidupan seorang pemimpin Kristen yang sejati harus mencerminkan kehidupan Kristus, oleh karena dia menjadi pemimpin atas pilihan dan panggilan Kristus dan juga menjamin keberhasilannya sebagai seorang pemimpin". ${ }^{10}$ Konsep kepemimpinan Kristen dilandasi keteladanan dan karakter dari kehidupan Kristus dan harus tunduk dan bertanggung jawab kepada Tuhan Yesus Kristus. Sedangkan menurut A.B. Susanto; "Didalam kepemimpinan gereja terdapat nilai-nilai universal berdasarkan semangat hidup Yesus yang memfokuskan diri pada manusia, oleh manusia dan untuk kepentingan manusia."11 Nilai-nilai kepemimpinan Kristen adalah semangat hidup Tuhan Yesus dan karunia-karunia Allah bagi kemuliaan Allah. Maka pola dasar kepemimpinan gereja adalah pola kepemimpinan Tuhan Yesus yaitu melayani yang seharusnya dilestarikan oleh setiap pemimpin gereja kepada generasi-generasi penerus kepemimpinan gereja.

${ }^{8}$ Yakob Tomatala, Kepemimpinan Dinamis, hlm. 43.

${ }_{9}$ Christ Marantika, Kepercayaan dan Kehidupan Kristen, (Jakarta: BPK Gunung Mulia, 1984)hlm. 404.

10 Ibid. hlm. 407.

${ }^{11}$ A.B.Susanto, Meneladani Jejak Yesus Sebagai Pemimpin, (Jakarta: Gramedia, 1997) hlm. 9. 


\section{Landasan Teologis Pemimpin Gereja Panggilan Pemimpin Gereja}

Setiap pemimpin gereja landasannya adalah karena panggilan Allah. Allah berdaulat atas semua manusia, untuk menetapkan, memilih, memanggil, menguduskan dan memperlengkapi setiap orang yang dikehendakiNya untuk memuliakan namaNya. Tentang dasar panggilan Allah bagi seorang pemimpin gereja, maka Yakob Tomatala menyatakan bahwa; "pemimpin gereja adalah seseorang yang telah dipanggil sebagai pemimpin yang ditandai oleh kapasitas memimpin, tanggung jawab pemberian Allah, untuk memimpin suatu kelompok umat Allah (gereja) mencapai tujuan bagi, serta melalui kelompok ini. ${ }^{12 " ~ j a d i ~}$ seorang pemimpin gereja harus sadar bahwa dirinya ditebus dan dipanggil Allahuntuk tanggung jawab sebagai pemimpin gereja

Tanda-tanda panggilan sebagai pemimpin gereja ialah menyadari bahwa dirinya dianugrahkan Allah kemampuan untuk memimpin gereja Tuhan baik secara organisasi maupun persekutuan orang-orang percaya dalam persekutuan dengan Tuhan dan sesame. Dasar teologis panggilan seorang pemimpin gereja adalah pelayan atau hamba Allah (Markus 10:42-45). Tugas dan tanggung jawab sebagai pemimpin gereja merupakan kepercayaan Allah untuk melayani Allah dan jemaatNya. Dengan demikian maka motifasi dasar dalam pelayanan sebagai pemimpin gereja ialah persekutuan yang hidup dengan Tuhan dan membina hubungan dengan jemaat Tuhan sebagai pengabdian.

\section{Pemimpin Gereja Menurut Alkitab Perjanjian Lama}

Pemimpin gereja bila ditinjau dari Alkitab Perjanjian Lama, maka ada dua sisi yaitu pemimpin bangsa dan pemimpin umat. Sejarah pemimpin bangsa bagi bangsa Israel mulai dari Musa, Yosua, para hakim, raja-raja mulai dari raja Saul. Raja-raja pada permulaan kerajaan yang sangat terkenal yaitu dari raja Saul, raja Daud dan Salomo kerajaan Israel sebagai kerajaan yang utuh dibawah kepemimpinan seorang raja. Setelah kepemimpinan raja Salomo kerajaan Israel terpecah jadi dua kerajaan yaitu kerajaan Israel dibagian selatan yang berpusat di kota Yerusalem dan kerajaan Yehuda dibagian utara yang berpusat di kota Samaria.

Tentang kepemimpinan bangsa dari bangsa Israel menurut Alkitab Perjanjian Lama, penulisa menyoroti kepemimpinan Musa. Tentang kepemimpinan Musa Andrew Murray mengatakan bahwa; “Abdi Allah betapa berartinya nama itu! Ini menjelaskan seseorang yang datang dari Allah, yang

\footnotetext{
12 Yakob Tomatala, Kepemimpinan Dinamis, Malang: Gandum Mas, 1997, hlm. 45.
} 
dipilih dan diutus; "13. Dalam pengertian bahwa Musa adalah pemimpin yang datang dari Allah dan diutus oleh Allah, karena Musa melangkah bersama Allah dalam persekutuan dan hadiratNya. Musa hidup dalam kehendak Allah dan dipimpin kemuliaan Allah untuk membawa umat Tuhan datang kepada Allah, karena Allah menempati hatinya yang benar.

Seharusnya setiap pemimpin gereja harus memilik motivasi untuk menjadi seorang abdi Allah yaitu mengabdikan seluruh hidupnya bagi pelayanan dan kemuliaan Allah. Pemimpin gereja yang mampu mempengaruhi orang lain untuk datang kepada Allah harus ada kuasa dan hadirat Allah dalam hidupnya karena persekutuan pribadinya dengan Allah seperti Musa. Musa dapat mempengaruhi Yosua untuk dipersiapkannya menggantikannya sebagai pemimpin bangsa Israel, karena ada wibawa Allah di dalam dirinya. Musa sebagai pemimpin memperlengkapi Yosua sebagai kader untuk melanjutkan tugas sebagai pemimpin gereja.

Mengenai panggilan Musa; "Sebagai pemimpin umat-Nya, Musa tidak hanya diperlengkapi secara teknis dengan pertumbuhan dan pendidikannya di Mesir. Tapi dalam hal yang paling asasi. Ia juga dibina menjadi pemimpin yang ulung berkat kesetiaannya mengikuti Allah oleh imannya. ${ }^{14 "}$ Orang seperti Musa inilah yang akan dibangkitkan Allah untuk memimpin umatNya. Meskipun Musa dipersiapkan Allah secara khusus untuk memimpin umat-Nya Israel keluar dari Mesir tanah perbudakan, namun proses yang panjang, dan tidak terlepas dari bsrbagai kendala.

Tentang fungsi kepemimpinan Musa dalam memperlengkapi generasi penerus, Ensiklopedi Alkitab masa kini jilid II, mengatakan: "Pada saat keluaran Yosua masih muda (Keluaran 33:11). Musa memilih dia membantu pribadinya, dan memberinya perintah membentuk pasukan terdiri dari suku-suku Israel yang belum terorganisir, untuk memukul mundur bangsa Amalek yang datang menyerang". ${ }^{15}$ Jadi Musa memilih dan mempersiapkan Yosua sejak keluar dari Mesir. Waktu Musa sendirian menghadap Allah di gunung Sinai, Yosua siaga menanti di kemah pertemuan (Keluaran 39:40; 40:2,6,7). Di dataran dekat sungai Yordan dia ditabiskan secara resmi sebagai pengganti Musa. Selama empat puluh tahun Musa mempeesiapkan Yosua sebagai pemimpin yang untuk melanjutkan kepemimpinannya.

${ }^{13}$ Andrew Murray, Pembaharuan Hari demi Hari Bagi Orang Percaya, (Batam: Interaksara, 2011) hlm. 39.

14 Ensiklopedia Alkitab Masa Kini jilid II, (Jakarta: Yayasan Bina Komunikasi Bina Kasih, 1997) hlm. 107.

${ }^{15}$ Ensiklopedi Alkitab Masa Kini jilid II, hlm. 227. 
Dalam kurun waktu empat puluh tahun, Yosua harus belajar dari kepemimpinan Musa yang panjang sabar, lemah lembut, melakukan perintah Tuhan dan belajar berhadapan dengan Allah. Pemimpin yang berkualitas, dan sukses adalah pemimpin yang dapat mempersiapkan bawahannya untuk pendelegasian tugas kepemimpinannya.

Musa tidak hanya mempersiapkan dan mendeligasikan tugas kepemimpinan kepada Yosua, namun atas nasehat mertuanya Musa memilih pemimpin seribu orang, seratus orang, lima puluh orang dan sepuluh orang dari orang-orang gagah perkasa, yang terkenal bijaksana untuk membantu Musa dalam menangani seluruh permasalahan kehidupan bangsa Israel, selama perjalanan di padang gurun (Keluaran 18:21-23).

Sedang pemimpin umat yang dimulai dari Harun dan anak-anaknya kemudian imam-imam dan nabi-nabi Allah. Dan pada point ini pembahasan akan difokuskan pada kepemimpinan umat Israel yaitu imam-imam dan nabinabi Allah. Para imam bertugas untuk mengelola ibadah di Kemah suci atau Bait Allah, sedangkan para nabi adalah penyambung lidah Allah yang bertugas untuk berbicara dan bertindak atas nama Allah.

Tentang pemimpin Israel penulis menyoroti pribadi nabi Yeremia. Tidak semua pemimpin gereja merasa layak dipakai untuk memimpin orang lain, karena kesadaran pribadi akan kehidupannya yang tidak luput dari dosa. Namun kesadaran dan perasaan berdosa tidak dapat membatasi panggilan Tuhan bagi setiap orang pilihan-Nya. Nabi Yeremia adalah salah seorang dari nabi besar dalam Alkitab, yang ketika dipanggil Tuhan merasa tidak layak menerima panggilan itu karena kehidupan yang berdosa.

Tentang tugas utama sebagai seorang nabi, LeRoy Eims mengatakan; tugas utama seorang nabi ialah memaklumkan Firman Allah kepada umatNya. Reaksi awalnya adalah perasaan tidak memadai. Ia tidak merasa sanggup melaksanakan tugas tersebut"16. Dalam hal ini seorang pemimpin umat adalah karena panggilan Tuhan. Panggilan pemimpin gereja peranan Tuhan yang sangat dominan karena ketetapan Tuhan. Ketetapan, pemilihan dan panggilan Allah bagi seorang pemimpin gereja adalah kehendak dan rencana Allah.

\section{Pemimpin Gereja Menurut Alkitab Perjanjian Baru}

Panggilan pemimpin gereja ditinjau menurut Alkitab Perjanjian Baru sama prosesnya dengan panggilan pemimpin gereja menurut Perjanjian Lama. Pada zaman Perjanjian Baru para pemimpin gereja bukan lagi imam-imam dan nabi-nabi, tetapi diganti oleh oleh Tuhan Yesus, para rasul, penilik-penilik

\footnotetext{
${ }^{16}$ LeRoy Eims, Jadilah Pemimpin Sejati, (Batam: Gospel Press, 2001) hlm. 21.
} 
jemaat, penatua-penatua, para gembala jemaat dizaman ini. Pada masa hidup dan pelayanan Tuhan Yesus ke dua belas rasulNya dipanggil, dipilih, dipersiapkan dan diutus untuk melaksanakan tugas yang dideligasikan Tuhan Yesus yaitu Amanat Agung (Matius 28:18-20).

Setelah kembali ke Sorga Tuhan Yesus memilih, memanggil, dan mengutus Paulus sebagai rasul terakhirNya. Rasul Paulus dikhususkan Tuhan untuk melayani bangsa-bangsa bukan Yahudi. Teantang pemimpin gereja pada zaman Perjanjian Baru, penulisan akan menyoroti kepemimpinan Tuhan Yesus dan Rasul Paulus.

Kepemimpin gereja pada zaman Perjanjian Baru bermuara pada pribadi Tuhan Yesus kepala gereja. Sebab hidup, karakter, keteladanan, visi dan pelayananNya yang menjadi landasan pelayanan gereja sampai saat ini. Membahas tentang hidup dan kepribadian Tuhan Yesus yang menjadi figure keteladanan gereja, maka Petrus Oktavianus mengatakan bahwa; Tokoh pemimpin yang paling memperkaya orang lain termasuk memperkaya pemimpin dunia ialah "Yesus Kristus". Semua sifat dan sikap yang sempurna yang kita perlukan hanya ada di dalam pribadi Yesus Kristus"17.

Oleh sebab itu kualifikasi seorang pemimpin rohani, yang terutama adalah ketergantungan kepada kepribadian, kerohanian, mental dan siafat-sifat sosial yang meneladani Yesus Kristus. Disusul dengan wibawa, intelektual, pengetahuan dan kebijaksanaanNya. Pemimpin gereja harus memanifestasikan seluruh eksistensi kehidupan Tuhan Yesus di dalam hidup dengan kekuatan kuasa Roh Kudus, di dalam pelayanannya untuk menuntun orang lain datang kepada TuahnYesus.

Membahas mengenai keteladanan hidup Tuhan Yesus bagi para pemimpin dan calon pemimpin gereja, maka Jerry C. Worffod mengatakan bahwa; Yesus meninggalkan suatu teladan dalam hal membimbing dan pemuridan. PelayananNya diperagakan dihadapan dihadapan kedua belas muridNya. Mereka mendengar Yesus mengajar, melihat Ia melakukan mujizat, mendengar Ia berdoa dan mereka melihat Ia tergantung di kayu salib"18. Maksudnya bahwa dalam pelayanan dan kepemimpinan Tuhan Yesus, muridmuridNya dilatih, diberdayakan dan dikembangkan karunianya dan diperlengkapi Tuhan melanjutkan visi dan pelayananNya.Tuhan Yesus tidak hanya melakukan transfer pengetahuan kepada para muridNya, menunjukkan karakter hidup yang baik.

17 Petrus Oktavianus, Manajemen dan Kepemimpinan Menurut Wahyu Allah, (Malang: YPPII, 1997) hlm. 191.

18 Jerry C. Woffrod, Kepemimpinan Kristen Yang Mengubahkan, (Yogyakarta: Yayasan Andi, 2001) hlm. 28. 
Pemimpin terbesar sepanjang masa yang pernah hidup sebagai manusia di dunia ini ialah Tuhan Yesus, yang kepemimpinan dan kehidupanNya sanggup mengubah dunia. Saat bersama para muridNya, Tuhan Yesus menunjukkan bahkan memberikan semua unsure kepemimpinan gereja mengubahkan dalam kepenuhanNya. Alkitab mencatat bahwa para murid belajar banyak tentang kehidupan, keteladanan, karakter, pelayanan sampai kepemimpinan Tuhan Yesus. Semuanya itu dilakukan Tuhan Yesus agar setiap pemimpin gereja mengekspresikan dalam pelayanan Tuhan Yesus agar visiNya dalam Amanat Agung tercapai.

Di saat seseorang menyerahkan hati dan hidupnya kepada Tuhan, maka dirinya berada dibawah pengawasan Allah. Setiap orang yang mau membuka hidupnya dihadapan Tuhan, maka Tuhan memperhitungkan itu sebagai kebenaran. Hanya karena anugerah Allah seseorang dapat melayani Allah, dan respons terhadap anugerah Allah adalah keterbukaan hidup dihadapan Allah. Hal ini terjadi dalam kehidupan rasul Paulus, yang sebelum dipanggil Tuhan adalah seorang penganiaya jemaat. Namun latar belakang hidupnya tidak hambat Tuhan untuk memilihnya menjadi rasulNya. Rasul Paulus mengakui membuka hidupnya dihadapan Tuhan dengan mengakui rencana dan tindakkannya untuk menganiaya jemaat Tuhan (I Korintus 15:9).

Tentang pengakuan rasul Paulus kepada Allah, maka LeRoy Eims mengatakan: "Seandainya ada orang yang latar belakang yang seharusnya menjadikannya tak terpakai oleh Allah, ialah rasul Paulus. Namun menjadi rasul terbesar bagi bangsa bukan Yahudi dan digunakan oleh, dan untuk menulis sebagian besar kitab Perjanjian Baru"19. Dari kisah hidup dan latar belakang rasul Paulus, yang menjadi pelajaran berharga bahwa hak prerogative Tuhan memanggil dan memilih seseorang, untuk melayani diridan pekerjaanNya tanpa melihat masa lalunya. Maksudnya bahwa sehitam apapun masa lalu seseorang, masa depannya masih tetap ada. Karena itu panggilan Tuhan adalah panggilan tertinggi untuk menrima tugas mulia dari bagi kemuliaanNya.

Mengenai panggilan Allah bagi seseorang Andrew Murray mengatakan, bahwa: 'Dengan anugerah kita dapat menjadi seorang abdi Allah! Orang yang mengetahui dan membuktikan tiga hal; Allah adalah segala sesuatu, Allah menuntut segalanya dan Allah mengerjakan semuanya"20. Jadi orang yang melihat Tuhan ditengah alam ciptaanNya dan didalam manusia, adalah Allah dari semua di dalam semua; orang yang mengerti bahwa Tuhan menuntun dan harus memiliki semuanya, orang yang hidup hanya untuk memberikan

\footnotetext{
${ }^{19}$ LeRoy Eims, Jadilah Pemimpin Sejati, hlm 25.

${ }^{20}$ Andrew Murray, Perubahan Hari Demi Hari Bagi Orang Percaya, hlm. 42
} 
kemuliaan yang adalah hak Tuhan; orang senantiasa berusaha seperti Anak Allah, untuk hidup di dalam ketergantungan yang tanpa hentinya kepada Allah didalam Yesus Kristus yang berfirman dan mengerjakan segalanya.

Kedewasaan rohani sangat diperlukan seorang pemimpin gereja. Seorang Kristen yang masih muda adalah seorang petobat baru, jadi jangan hendaknya diberi tanggung jawab. Sebab seorang pemimpin gereja bukan seorang pemarah, seorang yang baik hati dan bertindak berdasarkan akal; seorang pendamai yang selalu membawa damai. Seorang pemimpin gereja adalah pelayan yang didalam pelayanan itu diterima sebagai anugerah sebab pelayanan adalah kepercayaan Tuhan untuk kerjakan bagi kemuliaan Tuhan.

Menanggapi syarat-syarat pemimpin gereja maka Oswald Sanders mengatakan;

Siapa yang lebih memenuhi syarat yang diwajibkan dalam kepemimpinan gereja dari rasul Paulus, pemimpin yang tidak ada bandingnya? Disamping kekayaan pengalamannya sendiri, ia diterangi dan diberi inspirasi oleh Roh Kudus. Tiada ada satu sifatpun yang diperintahkan rasul Paulus merupakan sekedar tambahan, melainkan keharusan yang sangat perlu"21.

Persyaratan kepemimpinan dari rasul Paulus kepada Timotius dan Titus adalah peraturan-peraturan baku yang dijadikan standart untuk pemimpin gereja masa kini. Karena itu seorang pemimpin gereja tidak cukup dengan teori akademis tapi harus disertai pengalaman pelayanan gereja dalam tuntunan Roh Kudus lewat persekutuan dan kualifikasi pribadi dengan Tuhan.

Rasul Paulus adalah tokoh kepemimpinan gereja yang benar-benar hidup meneladani dan mencerminkan kepemimpinan Yesus Kristus. Karena keharmonisan hidupnya yang terpelihara dengan Tuhan, sehingga sewaktuwaktu kelihatan wajah seperti malaikat. Seharusnya para pemimpin gereja diakhir zaman ini dapat mencerminkan kehidupan Yesus didalam hidupnya seperti rasul Paulus.

\section{Pengertian Jemaat}

Pengertian jemaat menurut Kamus Besar Bahasa Indonesia; "Jemaat adalah sehimpunan umat; jemaah. ${ }^{22}$ " Jadi jemaat berarti himpunan umat yang hidup dalam persekutuan dengan Tuhan Yesus Kristus. Pembahasan tentang jemaat, penulis menyerotinya berdasarkan dua zaman Alkitab, yaitu:

${ }^{21}$ J.Oswald Sanderns, Kepemimpinan Rohani, (Bandung: Kalam Hidup, 1997) hlm. 32.

${ }^{22}$ Kamus Besar Bahasa Indonesia, (Jakarta: Balai Pustaka, 2002). Hlm. 467. 
Pada zaman Alkitab Perjanjian Lama orang-orang Israel disebut sebagai uamt Allah yang dilayani oleh para imam dan para Nabi Allah. Kata Umat didefenisikan bahwa; "Umat adalah para penganut (pemeluk, pengikut) suatu agama"23. Jika pengertian umat ditinjau dari sudut pandangan iman Kristen maka umat yang dimaksudkan dalam defenisi diatas adalah umat Allah, karena pada zaman Perjanjian Lama bangsa Israel disebut sebagai umat Allah.

Tentang kepribadian Abraham maka penulis Tafsiran Alkitab Masa kini jilid I menjelaskan bahwa: "Perbuatan-perbuatan ketaatannya dalam iman dapat dipakai sebagai teladan, dan membuat dia diberi gelar 'sahabat Allah', yaitu seorang yang mengejawatankan kesetiaan kepada Allah"24. Namun Abraham dipilih dan dipanggil Allah hanya karena anugerah Allah, bukan karena Abraham memenuhi kriteria-kriteria khusus yang ditetapkan sebagai kualifikasi yang ditetapkan Allah. Umat Allah yang adalah bangsa Israel, bermula dari pilihan dan panggilan Allah kepada Abraham (Kejadian 12:1-9).

Kehadiran Tuhan Yesus di dunia mengajarkan tentang Kerajaan Allah. Demikian juga ketika Tuhan Yesus mengutus muri-muridNya untuk membawa kabar baik, memberitakan tentang Kerajaan Allah, yaitu Pemerintahan Allah bukan tentang Jemaat (Matius 10:7). Namun Tuhan Yesus berbicara tentang kunci Kerajaan Sorga yang merupakan pernyataan Tuhan Yesus untuk pertama kalinya mengenai akan adanya jemaat yang akan dirikan-Nya (Matus 16:18-19). Jelas bahwa pernyataan Yesus dalam ayat-ayat ini bersifat kiasan dan bermaksud untuk merujuk kepada suatu kehidupan yang baru yang didalamnya kehendak Allah menjadi norma kehidupan.

Selanjutnya mengenai pandang Rasul Paulus tentang jemaat Tuhan yang dilayaninya Donald Guthrei mengatakan:

"Paulus memandang Jemaat menurut dua cara utama. Dalam kebanyakan surat-suratnya, yang dimaksudkan dengan "jemaat" ialah perhimpunan orang-orang percaya dalam suatu daerah tertentu. Surat-surat ditujukan kepada Korintus dialamatkan "kepada Jemaat Allah di Korintus" (I Korintus 1:2; II.Korintus 1:1) ....surat-surat yang lain ditujukan kepada orang-orang kudus di Roma, Filipi, Kolose"25.

Dari pernyataan di atas menjelaskan bahwa kata jemaat digunakan dalam pengertian sekelompok orang-orang percaya dalam suatu daerah setempat dan pengertian jemaat secara universal.

${ }^{23}$ Ibid, hlm. 1242.

${ }^{24}$ Tafsiran Alkitab Masa Kini 1, (Jakarta: Yayasan Komunikasi Bina Kasih,2008), hlm. 100.

25 Donald Guthrie, Teologi Perjanjian Baru 3, (Jakarta: BPK Gunung Mulia, 1998) hlm. 69. 
a. Jemaat Sebagai Satu Tubuh Kristus.

Dalam surat-surat rasul Paulus sering menyebut jemaat Tuhan sebagai tubuh Kristus. Kiasan mengenai tubuh adalah yang paling hidup dan penuh arti. Dalam suratnya kepada jemaat di Roma rasul Paulus memakai istilah tubuh untuk mengajarkan bahwa karunia-karunia yang berbeda itu bias dipakai didalam satu tubuh (Roma 12:4-8). Jemaat digambarkan sebagai satu tubuh, tubuh manusia memberikan gambaranmengenai hubungan Tuhan Yesus Kristus dengan orang-orang percaya (I Korintus 12:12).

Donald Guthri mengatakan bahwa: "Gagasan mengenai tubuh Kristus ini menunjukkan betapa eratnya ikatan yang mempersatukan semua orang percaya. Tentu yang dimaksudkan dengan tubuh dalam konteks ini ialah jemaat setempat tetapi hal ini penting mengingat adanya karunia-karunia rohani yang berbedabeda yang sedang dinyatakan"26. Tubuh yang dimaksudkan adalah tubuh Kristus, sedangkan perbedaan yang dimaksudkan adalah karunia-karunia yang berbeda di dalam jemaat yang diperlukan untuk kepentingan masing-masing anggota supaya tubuh Kristus yaitu gereja dapat berfungsi secara efisien. Disinilah terdapat pandangan jemaat yang bersifat kebersamaan.

Dapat dikatakan bahwa kiasan tentang tubuh dalam pengajaran rasul Paulus sangat membantu pemahaman untuk mengerti hubungan Tuhan Yesus sebagai kepala dan dengan jemaatNya sebagai anggota-anggota tubuh. Dalam pengertian bahwa seluruh orang percaya membentuk tubuh Yesus Kristus (I Korintus 6:15).

b. Jemaat Sebagai Pengantin Perempuan

Jemaat sebagai pengantin perempuan terlihat dari beberapa perumpamaan yang dipakai Tuhan Yesus dalam beberapa kali pengajaranNya. Perumpamaan Tuhan Yesus tentang "Gadis-gadis yang bijaksanaan dan Gadisgadis yang bodoh" (Matius 25:1-13) dan "Perumpamaan tentang Perjamuan kawin" (Matius 22:1-14). Dari kedua perumpamaan ini Tuhan Yesus menggambarkan hubunganNya dengan jemaatNya.

Yohanes pembaptis menggambarkan hubungan Tuhan Yesus dengan jemaatNya sebagai mempelai perempuan dan mempelai laki-laki (Yohanes 3:2930). Maksud Yohanes pembaptis untuk bedakan dirinya dari Yesus Kristus sebagai mempelai laki-laki dan jemaat sebagai mempelai perempuan.

Rasul Paulus menggambarkan Tuhan Yesus dan jemaatNya seperti hubungan suami dengan istri (Efesus 5:25). Walaupu pada ayat ini jemaat tidak

${ }^{26}$ Ibid hlm. 71. 
disebut sebagai mempelai atau pengantin perempuan, namun tepat pada analogi hubungan Tuhan Yesus dengan jemaatNya.

\section{Landasan Theologis Memperlengkapi Jemaat}

Pembahasan tentang landasan teologis memperlengkapi jemaat bagi pembangunan tubuh Kristus atau pertumbuhan gereja maka penulis menyoroti dari dua sudut pandang Alkitab, yaitu:

\section{Dasar Theologi Perjanjian Lama}

Dasar Alkitab Perjanjian Lama upaya memperlengkapi jemaat adalah tujuan penciptaan oleh Allah. Sebelum menciptakan manusia, Allah Tritunggal bermusyawarah dan bermufakat, untuk tujuan penciptaan manusia. Tentang penciptaan manusia maka Soedarm menyatakan bahwa;

Tuhan Allah menjadikan makluk-makluk lain hanya berfirman saja; 'jadilah ini' dan 'jadilah itu'. Tetapi ketika Tuhan menjadikan manusia, Ia bermusyawarah. Hal ini menunjukkan bahwa terjadinya manusia direncanakan dulu diantara Allah Bapa, Putra dan Roh Kudus, "Baiklah Kita menjadikan manusia” (Kejadian 1:26). Rencana itu menyatakan bahwa pekerjaan menjadikan manusia itu lebih penting dari pada menjadikan manusia"27.

Lalu Allah yang menciptakan manusia menurut gambar dan rupaNya baik lakilaki dan perempuan. Kemudian Allah memberkati manusia untuk beranakcucu dan berkuasa atas ciptaan Allah yang lainnya (Kejadian 1:26-28). Kemudian tujuan Allah menciptakan manusia dijelaskan lagi dalam (Kejadian 2:15; 20). Jadi tujuan Allah agar manusia menjadi rekan sekerja Allah.

Kesepakatan Allah tritunggal dalam menciptakan manusia, menunjukkan bahwa manusia itu sangat berharga dimata Tuhan, sehingga diciptakan pada hari terakhir sebagai puncak penciptaan Allah. Waktu Allah menjadikan manusia tidak hanya berfirman, tetapi dengan kasih Allah membentuk manusia dari tanah liat menurut rencana kasihNya, kemudian Allah menghembuskan nafas hidupNya kedalam tubuh manusia.

Kata gambar dan rupa Allah secara etimologi dapat didefenisikan terpisah yaitu kata 'gambar' berarti yang menjadi pokoknya, sedangkan 'rupa' berarti' bahwa gambar itu sudah mirip. Jadi kalimat gambar dan rupa Allah berarti secara khusus berarti pada manusia ada pengetahuan, kebenaran dan kesucian Allah. Sedangkan secara umum berarti segala sifat manusia yang membedakan 
manusia dengan makluk lain yaitu pikiran, kemauan, jiwa, dan roh. Maka menurut Harun Hadiwijono mengatakan bahwa: "Menjadi gambar atau dijadikan menurut gambar dan rupa Allah berarti, bahwa manusia dipanggil untuk mencerminkan hidup ilahi di dalam hidupnya. Dan penggilannya hanya mungkin dilaksanakan jikalau manusia mentaati kehendak Allah, mengarahkan wajahnya kepada Allah"28. Berdasarkan pernyataan ini maka dapat disimpulkan bahwa kejatuha manusia ke dalam dosa, tidak lagi mencerminkan kehidupan ilahi sebagai gambar dan rupa Allah di dalam kehidupannya. Kerusakkan gambar dan rupa Allah di dalam pribadi manusia, karena manusia lebih memilih untuk menjadi dirinya sendiri.

\section{Dasar Teologi Perjanjian Baru}

Dasar Alkitab upaya memperlengkapi manusia merupakan mandat karya penebusan Allah dalam Tuhan Yesus Kristus bagi manusia. Membahas tentang karya penebusan manusia dari kuasa dosa oleh Allah, maka J. Verkuyl mengatakan bahwa:

Sejak dari taman Firdauspun Tuhan telah beri janji kepada manusia yang telah jatuh kedalam dosa itu. Janji itu adalah pemberitahuan tentang rencana penyelamatan oleh Tuhan. Janji itu disebut: Injil pertama, janji induk yaitu seorang penolong akan datang kelak, dilahirkan dari si perempuan dan Ia akan menginjak-injak kepala si ular"29.

Seorang penebus yang dilahirkan dari keturunan perempuan yaitu Tuhan Yesus Kristus, karena karunia Roh Kudus yang mampu mengerjakan pekerjaanpekerjaan Allah. Tentang keilhaian dan kemanusia Tuhan Yesus Kristus dalam karya penebusan maka Harun Hadiwijono mengatakan bahwa:

bahwa Kristus adalah manusia sejati, yang lahir dari seorang perempuan, seperti halnya dengan manusia yang lain, yang selanjutnya mengalami perkembangan jasmanidan rohani seperti halnya dengan segala mnusia, akan tetapi dilain pihak Alkitab juga menceritakan bahwa Kristus adalah Allah sejati, yang bersama-sama dengan Allah dan Allah adanya, yang menjadikan segala makluk serta menghidupinya yang membaharui segala yang telah dijadikanNya"30.

Yesus Kristus adalah pribadi Allah yang menjadi manusia untuk menyelamatkan manusia dari kuasa dosa, sesuai dengan janji Allah dalam

\footnotetext{
${ }^{28}$ Harun Hadiwijono, Iman Kristen, Jakarta: BPK: Gunung Mulia, 1992, hlm. 204.

29 J.Verkuyl, Aku Percaya, Jakarta: BPK. Gunung Mulia, 1995) hlm. 106.

${ }^{30}$ Harun Hadiwijono, Iman Kristen, hal. 307-308.
} 
Kejadian 3:15. Maka Rasul Paulus mengatakan bahwa: Tuhan Yesus Kristus adalah Allah, yang sudah mengosongkan diri dan mengambil rupa seorang hamba dan menjadi sama dengan manusia (Filipi 2:6-8).

Selanjutnya Billy Graham, mengatakan bahwa: Ia yang tidak mengenal dosa telah dijadikan dosa karena kita dapat menjadi kebenaran Allah di dalam Dia. Pada kayu salib Ia menjadi dosa. Ia ditinggalkan Allah. Sebab Ia tidak mengenal dosa ada suatu nilai yang tidak terukir besarnya dalam hukuman yang Ia tanggung bukan karena kesalahannya sendiri"31. Tuhan Yesus menderita bahkan sampai mati dikayu salib karena Allah ingin menyelamatkan manusia dan menjadi umat atau jemaat Allah yang diperlengkapi untuk mengembalikan gambar dan rupa Allah yang telah hilang dari manusia, (Kejadian 1:26-28; 2:15; 20).

\section{Pertumbuhan Gereja}

Pada point ini akan dibahas arti gereja dari beberapa sudut pandang yaitu; gereja dari perspektif persekutuan orang-orang percaya; gereja dari perspektif organisasi dan gereja dari perspektif tempat persekutuan orangorang percaya. Gereja adalah persekutuan orang-orang percaya yang dipanggil Allah keluar dari kegelapan dosa kepada terang yang ajaib untuk memberitakan perbuatan-perbuatan Allah yang besar (1 Petrus 2:9-10).

Arti gereja menurut Kamus Besar Bahasa Indonesia adalah; "(1). Gedung (rumah) tempat berdoa dan melakukan upacara Kristen. (2). Badan (Organisasi) umat Kristen yang sama kepercayaan, ajaran dan tata cara ibadahnya"32. Defenisi ini dari perspektif gereja sebagai gedung tempat berbagai kegiatan serimonial kekristenan dijalankan dan dari perspektif gereja sebagai organisasi yang menata pelayanan gereja. Karena itu secara umum gereja dipandang dari bangunan tempat beribadah, sedangkan secara manajemen dan hokum gereja dipandang sebagai organisasi.

Mengenai defenisi gereja Christ Marantika mengatakan bahwa;

Kata gereja bila diselidiki maka menurut bahasa Yunani "Ekklesia" artinya orang-orang yang dipanggil keluar dari kegelapan oleh Injil Yesus Kristus untuk datang kepada terang ajaib. Maka, menurut ajaran Alkitab, arti gereja tidak menunjuk kepada gedung tempat ibadah atau suatu aliran gereja. Gereja adalah orang-orang yang telah dipanggil keluar dari

31 Billy Graham, Berdamai dengan Allah, Jakarta: Yayasan Komunikasi Bina Kasih, 1988) hl 121.

\footnotetext{
32 Kamus Besar Bahasa Indonesia, (Jakarta: Balai Pustaka, 2002) hlm 357.
} 
dunia oleh Injil Yesus Kristus, disatukan oleh iman dalam Yesus Kristus untuk melakukan kehendak Allah"33.

Secara etimologi, maka defenisi gereja menurut bahasa asli Alkitab (bahasa Yunani) adalah orang-orang tebusan Yesus Kristus dari dosa untuk hidup dalam persekutuan dengan Tuhan Yesus Kristus. Dari defenisi ini dapat dipahami bahwa gereja adalah organism yang akan terus secara dinamis yang tak akan bias dihambat oleh siapapun, dengan apapun dan dengan bagaimanapun. Sesungguhnya gereja hidup, bergerak sesuai metode-metode dan terobosanterobosan Tuhan Yesus Kristus sang kepala gereja.

Namun fungsi gedung gereja juga penting dalam pelaksanaan kegiatankegiatan serimonial gereja, maka Suhento Liauw mengatakan:

Kata gereja berasal dari bahasa Portugis "Igreja" sedangkan" dan kata jemaat berasal dari bahasa Arab "Jemaah". pengertian ini sama dengan makna kata dalam bahasa Inggris memiliki dua ungkapan yaitu "Church" dan "Assembly" dipakai untuk menunjukkan pada orang-orangnya. Apabila disejajarkan dalam bahasa Indonesia, "Church adalah gereja" dan "Assembly adalah jemaat"34.

Gereja harus dilihat dari tiga pengertian baik secara organism yaitu persekutuan orang-orang percaya, tempat persekutuan orang-orang percaya, maupun organisasi yang menata pelayanan gereja, karena ketiganya merupakan satu kesatuan yang selalu bersama dan tidak terpisahkan.

Sedangkan Abineno mendefeniskan gereja dari bentuk permunculannya di dunia dan mengatakan bahwa; "tetapi kalau kita melihat dari sisi hakekatnya, ia pada lain pihak adalah suatu persekutuan rohani dengan Yesus Kristus sebagai kepala. Sebagai persekutuan rohani, ialah adalah "objek dari percaya atau iman Kristen"35. Gereja adalah suatu perkumpulan manusia biasa, yang mempunyai kebiasaan-kebiasaan tertentu yang berpusat pada Tuhan Yesus. Kegiatan gereja berfokus pada pembinaan iman Kristen agar mencerminkan kehidupan Tuhan Yesus sebagai sumber semua pengajaran dan berbagai kegiatan gereja.

Secara umum gereja dapat didahami dari tiga pengertian yaitu; (1). Gereja adalah persekutuan orang-orang percaya (Organisme), (2). Gereja adalah tempat persekutuan orang-orang percaya dan (3). Gereja adalah organisasi yang menata pelayanan dan menaungi secara hukum. Ketiga pengertian gereja tersebut saling

${ }^{33}$ Christ Marantika, Kepercayaan dan Kehidupan Kristen, hlm. 183.

${ }^{34}$ Suhento Liauw, Doktrin Gereja Alkitabiah, (Jakarta: Graphe, 1996), hlm. 43-44.

35 J.l.Ch. Abineno, Garis-garis Besar Hukum Gereja, (Jakarta: BPK. Gunung Mulia, 1994), hlm 3. 
membutuhkan dan melengkapi dalam menjalankan dan mewujudkan visi kelapa gereja yaitu memenangkan dunia bagi Allah.

Pengertian gereja menggambarkan ketritunggalan Allah yang bereksistensi dan hidup, dan tidak akan mungkin gereja dimusnahkan oleh dunia yang fana dan sementara ini. Gereja bukan dari dunia ini tapi datang ke dunia untuk menerangi dunia yang dalam kegelapan.

\section{Pengertian Pertumbuhan Gereja}

Pengertian pertumbuhan gereja menurut John Virgil; "Pertumbuhan lebih menjelaskan dinamika atau sifat dan kinerja dari sifat dan eksistensi gereja. Artinya kondisi pertumbuhan gereja inilah yang menyebabkan gereja dapat eksis secara dinamis dan tiga statis"36. Jadi pertumbuhan gereja secara teologis yakni sebagai manifestasi atau perwujudan Amanat Agung Tuhan Yesus Kristus untuk mengembangkan gereja dalam segala jenis pertumbuhan.

\section{Landasan Theologis Pertumbuhan Gereja}

Landasan pertumbuhan gereja adalah Alkitab, maka pembahasan tentang pertumbuhan gereja penulisa membahasnya dari sudut pandang Alkitab. Karena landasan pertumbuhan gereja dapat ditinjau dari dua konsep Alkitab yaitu Konsep Alkitab Perjanjian Lama dan Konsep Alkitab Perjanjian Baru.

\section{Gereja Dalam Perjanjian Lama}

Pertumbuhan gereja menurut konsep Perjanjian Lama, dilihat dari mandate Allah kepada Adam (Kejadian 1:28). Tentang mandat Allah kepada manusia John Virgil mengatakan bahwa: "Berkat Allah dan panggilan fungsional Allah kepada Adam, yakni untuk berkembangbiak dan memenuhi bumi. Hal ini juga, dapat dikatakan sekaligus merupakan mandate Allah bagi pertumbuhan gereja"37. Apabila Allah yang mendatangkan pemerintahkan pertumbuhan gereja, maka tidak akan mungkin Allah tidak memperhatikan pertumbuhan gerejaNya.

Selanjutnya mandate Allah kepada Abraham yang secara spesifik dipanggil dan ditetapkan Abraham untuk menjadi bangsa yang besar agar memberkati banyak bangsa (Kejadian 12:1-3). David F. Hinson mengatakan; "Berita Alkitab mengenai sejarah Israel dimulai dengan panggilan Allah kepada Abraham untuk hlm. 6

${ }^{36}$ John Virgil, Kompleksitas Pertumbuhan Gereja, (Jakarta: Yayasan Kasih Imanuel, 2001)

37 Ibid, hlm.13. 
menjadi bapa bagi suatu bangsa baru"38. Artinya Allah memilih, memanggil Abraham dan menetapkannya untuk menimbulkan satu bangsa lewat keturunannya dan Allah akan memfokuskan perhatian dan konsentrasiNya hanya kepada keturunan Abraham. Bangsa dari keturunan Abraham inilah yang disebut bangsa Israel atau bangsa pilihan Allah, sebagai gambaran pertumbuhan gereja menurut Alkitab Perjanjian Lama.

Anugerah keselamatan Allah sampai ke seluruh bangsa di bumi lewat bangsa Israel, sebagai penggenapan janji Allah kepada Abraham untuk menjadi berkat bagi banyak bangsa (Kejadian 12:2) yang dinyatakan Allah, di dalam Tuhan Yesus Krisrus lewat Amanat AgungNya (Matius 28:18-20).

\section{Gereja Dalam Perjanjian Baru}

Menurut rasul Paulus, panggilan Allah kepada Abraham dalam Kejadian 12:3 adalah penginjilan Allah; "Dan kitab suci yang sebelumnya mengetahui, bahwa Allah membenarkan orang-orang bukan Yahudi karena iman, telah terlebih dahulu memberitakan Injil kepada Abrahm "Olehmu segala bangsa akan diberkati" (Galatia 3:8). Namun bila dilihat dasar pertumbuhan gereja dari sisi penginjilan, maka awal penginjilan Allah pertama di dunia ialah Kejadian 3:15. Sebab ketika manusia jatuh dalam dosa saat itupun Allah mencari manusia, dan membuat suatu perjanjian bahwa keturunan perempuan yang akan menyelamatkan manusia dari dosa.

Pada dasarnya bahwa petumbuhan gereja berawal dari penginjilan yang dimulai oleh Allah kepada manusia. Bila dilihat dan dipahami dengan benar, maka tindak Allah untuk mencari dan menyelamatkan manusia adalah dasar pertumbuhan gereja yang Alkitabiah pada zaman Perjanjian Baru (Matius 28:18-20; Kisah Para Rasul 1:8) dimana Tuhan menginginkan semua manusia diselamatkan dari kuasa dosa lewat pemberitaan firman Tuhan dan kuasa Roh Kudus.

Dalam pelayananNya di dunia Tuhan Yesus, telah meletakkan dasar pertumbuhan gereja, ketika mengatakan kepada Simon Petrus; "Dan Akupun berkata kepadamu: Engkau adalah Petrus dan atas batu karang ini Aku akan mendirikan jemaatKu dan alam maut tidak akan menguasainya" (Matius 16:18). Dengan demikian maka John Virgil mengatakan, bahwa: "Istilah membangun jemaat tidak sekedar eksisnya gereja Tuhan atau jemaat di muka bumi ini, tetapi juga memiliki arti atau makna implicit bahwa itu akan bertumbuh dan terus

38 David F.Hinson, Sejarah Israel Pada Zaman Alkitab, (Jakarta: BKP. Gunung Mulia, 1996) hlm 30 . 
bertambah kearah kesempurnaannya dalam Kristus"39. Dengan demikian dapat dipahami bahwa pertumbuhan gereja adalah kedaulatan dan kemaha kuasaan Allah secara absolute bagi gereja-Nya.

Agar tidak sekedar eksis, maka dalam upaya pertumbuhan gereja harus meneladani Tuhan Yesus, yang memulai pelayanan-Nya yang mengubahkan dunia sampai saat ini hanya dengan secara khusus mempersiapkan dua belas orang rasul-Nya selama tiga setengah tahun. Ketika hendak kembali ke Sorga para rasul-Nya dipercayakan mandatNya yang lebih dikenal dengan istilah amanat agung Tuhan Yesus (Matius 28:18-20), dan saat sebelum terangkat ke Sorga di bukit Zaitun menjanjikan pencurahan Roh Kudus sebagai dunamos atau kekuatan dari Allah untuk pertumbuhan gereja Tuhan Yesus Kristus.

Tentang proses pertumbuhan gereja mula-mula, maka Th. Van den End, mengatakan bahwa: "Jemaat Kristen pertama terdiri dari orang-orang Yahudi. Orang-orang Yahudi-Kristen itu tetap mengunjungi Bait Allah dan Sinangoge dan mentaati hukum Taurat dengan setia, (Kisah Para Rasul 2:46; 3:1)"40. Jadi gereja mula-mula dimulai dari orang Yahudi yang bertobat karena Injil, yang walaupun hidup dalam komunitas sebagai pengikut Kristus, namun tetap dengan setia mengunjungi Bait Allah dan Sinagoge untuk beribadah kepada Allah.

Dasar pertumbuhan gereja dalam konteks Perjanjian Lama, merupakan tindakkan Allah mencari dan menyelamatkan manusia saat manusia jatuh dalam dosa dalam Kejadian 3:15 yang kemudian ditindaklanjuti dengan panggilan Allah kepada Abraham untuk menjadi berkat bagi banyak bangsa di bumi. Karena itu maka bentuk pertumbuhan gereja dalam Perjanjian Lama dalam bentuk kuantitas. Sedangkan pertumbuhan gereja pada zaman Perjanjian Baru bermula dari penginjilan, pemuridan, pengkaderan, pengeligasian dan pengutusan rasul-rasul oleh Tuhan Yesus Kristus, untuk menjadi semua bangsa menjadi muridNya dengan tuntunan dan kekuatan kuasa dari Roh KudusNya (Matius 28:18-20; Kisah Para Rasul 1:8). Karena itu maka bentuk pertumbuhan gereja dalam Perjanjian Baru adalah dalam bentuk kualitas.

\section{Kesimpulan}

Dalam pembahasan tentang pertumbuhan gereja, John Virgil mengatakan bahwa; "Ada dua bentuk pertumbuhan gereja yaitu pertumbuhan kuantitatif dan

\footnotetext{
39 John Virgil Kompleksitas Perkembangan Jemaat, hlm. 11.

40 Th. Van den End, Harta Dalam Bejana, (Jakarta: BPK. Gunung Mulia, 1995) hlm. 17.
} 
pertumbuhan kualitatif"41. Kedua bentuk pertumbuhan gereja ini harus seimbang, karena dampak dari pertumbuhan gereja kualitatif adalah pertumbuhan gereja secara kuantitatif, sebaliknya pertumbuhan gereja secara kuantitatif sebagai dampak dari pertumbuhan gereja secara kualitatif.

\section{Pertumbuhan Gereja Secara Kuantitatif}

Pertumbuhan gereja secara kuantitatif adalah penambahan jumlah anggota jemaat dalam gereja. "Didalam menerangkan dan untuk mengetahui pertumbuhan gereja secara kuantitatif, satu-satunya cara yang paling kongkrit ialah melalui laporan dan statistic bilangan yang didata secara akurat pihak gereja" ${ }^{42}$. Jadi pertambahan jumlah jemaat dalam sebuah gereja local merupakan barometer dalam mengetahui pertumbuhan gereja. Dengan demikian maka penulis menyorotinya dari tiga bentuk pertambahan jumlah jemaat, sebagai pertumbuhan gereja secara kuantitatif, yaitu:

\section{Pertumbuhan Karena Pertobatan}

Pengertian pertumbuhan gereja secara kuantitatif karena pertobatan, adalah pertambahan jumlah bilangan orang percaya dalam gereja Tuhan, karena pertobatan orang-orang berdosa. Orang-orang berdosa yang dimaksud bertobat dan menjadi anggota gereja karena pemberitaan firman Tuhan. Pertumbuhan gereja yang demikian merupakan dampak dari pada gerakan penginjilan jemaat Tuhan yang membawa jiwa-jiwa baru kepada Tuhan Yesus Kristus. Allah menghendaki pertumbuhan gereja karena pertobatan, supaya manusia hidup dalam persekutuan dengan diri-Nya. Pertumbuhan gereja karena pertobatan, merupakan penggenapan Amanat Agung Tuhan Yesus Kristus kepada para muridNya (Matius 28:18-20).

Mengenai pertobatan karena penginjilan, Rick Warren berkata; "Agar gereja anda sangat efektif dalam penginjilan, anda harus menentukan suatu targaet. Ketahuilah jenis orang bagaimana yang tinggal didaerh anda dan tentukan kelompok-kelompok mana yang mana yang sanggup dijangkau oleh gereja anda"43. Jadi walaupun gereja tidak mampu menjangkau semua orang, gereja harus tahu golongan orang-orang yang cocok untuk dijangkau. Gereja harus menjangkau semakin mungkin orang walaupun tidak semua golongan orang dapat dijangkaunya.

\section{Pertumbuhan Karena Perpindahan}

\footnotetext{
${ }^{41}$ John Virgil, Kompleksitas Pertumbuhan Gereja, hlm. 20.

42 Ibid hlm. 20.

${ }^{43}$ Rick Warren, The Purpose Driven Church, Malang: Gandum Mas, 2005, hlm. 89.
} 
Pengertian pertumbuhan gereja kuantitatif ialah jumlah anggota jemaat bertambah karena perpindahan anggota gereja dari gereja yang ke gereja yang lain dengan berbagai alasan. Misalnya karena urbanisasi yaitu jemaat pindah dari desa ke kota dan menetap mlalu menjadi anggota di salah satu gereja di kota. Perpindahan jemaat bisa antar denominasi gereja, karena alasan doktrin atau pengajaran, pertumbuhan iman atau juga karena factor keluarga atau karena alasan pernikahan.

\section{Pertumbuhan Karena Biologis}

Pengertian pertumbuhan gereja kuantitatif dari segi biologis terjadi karena anak-anak dari keluarga-keluarga Kristen yang tumbuhan menjadi dewasa dan kemudian menikah lalu menjadi anggota jemaat pada gereja tersebut. Sebagian besar gereja diseluruh dunia bertumbuh dan berkembang dengan cara demkan.

Pertumbuhan gereja secara kuantitatif dari segia biologis disebut juga pertumbuhan melalui keturunan orang percaya, yang merupkan penggenapan amanat Allah ke Adam dan Abraham untuk beranak cucu memenuhi bumi (Kejadian 1:28; 17:6). Pertumbuhan gereja seperti ini pasti terjadi di dalam gereja.

\section{Pertumbuhan Gereja Secara Kualitatif}

Pertumbuhan gereja merupakan amanat Allah, yang harus dikerjakan sesuai pola Allah untuk menjangkau seluruh umat manusia bagi Allah. Jadi gereja sebagai alat Tuhan untuk mengembalikan manusia yang terpisah dari Allah karena dosa. Pertumbuhan gereja secara kualitatif, merupakan landasan gereja yang kokoh bagi pertumbuhan gereja secara kuantitatif. Mengenai pertumbuhan gereja secara kualitatif, maka John Virgil, mengatakan; "Jika hanya memegahkan pertumbuhan bilangan, dan melalaikan kualitas yang sebenarnya, maka mengalami suati kesalahan. Apabila kualitas maju mencapai bilangan, maka akan dicatat dan dismpan sebagai arsip, dan fakta yang menandakan pertumbuhan kualitas" ${ }^{\prime 4}$. Kualitas orang Kristen mencakup kehidupan yang diperolehnya, karena ketaatan dari hasil penginjilan dan kesaksian hidup. Artinya bahwa pertumbuhan gereja secara kualitas selalu lebih diprioritaskan dari pada pertumbuhan gereja secara kuantitas, sebab segala sesuatu yang berkualitas pasti berkuantitas.

Tuhan Yesus memulai pelayanan pertumbuhan gereja hanya dengan mempersiapkan kualitas hidup dua belas orang rasulNya, dan walau diriNya adalah Tuhan namun dari ke dua belas orang rasul itu satu orangnya gugur.

\footnotetext{
${ }^{44}$ John Virgil, Kompleksitas Pertumbuhan Gereja, hlm.22.
} 
Namun dari kualitas hidup ke sebelas orang yang dipersiapkanNya itu, hasilnya mampu mengubah dunia sampai hari ini.

Seperti halnya Tuhan Yesus memperlengkapi para muridNya, demikian juga, gereja harus memperlengkapi jemaatnya secara kualitas seperti kelas pendalaman Alkitab, pemuridan serta kelas penginjilan dan pertumbuhan gereja (Efesus 4:11-12). Gereja mula-mula juga memperlengkapi jemaat yaitu tiap-tiap hari kumpul menerima firman Tuhan dari para rasul (Kisah para rasul 2:41-47).

Jadi pada dasarnya pertumbuhan gereja secara kualitatif harus dimulai dari upaya memimpin gereja memperlengkapi jemaat lewat berbagai metode pengajaran firman Tuhan yang Alkitabiah.

\section{Rerefensi}

A.M. Mangunhardjana, Kepemimpinan, Yogyakarta: Kanasius, 1976)

Muhammad Ali, Kamus Lengkap Bahasa Indonesia Modern, Jakarta: Pustaka Amani, t.th.

Tim penyusun Kamus Besar Bahasa Indonesia, Jakarta; Balai Pustaka 2001 J.Oswald Saners, Kepemimpinan Rohani, Bandung: Yayasan Kalam Hidup, 2001. Evendhy M. Siregar, Bagaimana Menjadi Pemimpin Yang Berhasil, Jakarta; 1998.

Yakob Tomatala, Kepemimpinan yang dinamis, Jakarta: Leadership Foundation, 1997

Agus Lay, Manajemen Pelayanan, Malang: Lembaga Pelayanan Mahasiswa Indonesia, 1998

Christ Marantika, Kepercayaan dan Kehidupan Kristen, Jakarta: BPK Gunung Mulia, 1984.

A.B.Susanto, Meneladani Jejak Yesus Sebagai Pemimpin, Jakarta: Gramedia, 1997.

Andrew Murray, Pembaharuan Hari demi Hari Bagi Orang Percaya, Batam: Interaksara, 2011.

Ensiklopedia Alkitab Masa Kini jilid II, Jakarta: Yayasan Bina Komunikasi Bina Kasih, 1997

LeRoy Eims, Jadilah Pemimpin Sejati, Batam: Gospel Press, 2001.

Petrus Oktavianus, Manajemen dan Kepemimpinan Menurut Wahyu Allah, Malang: YPPII, 1997.

Jerry C. Woffrod, Kepemimpinan Kristen Yang Mengubahkan, Yogyakarta: Yayasan Andi, 2001.

Kamus Besar Bahasa Indonesia, Jakarta: Balai Pustaka, 2002.

Tafsiran Alkitab Masa Kini 1, Jakarta: Yayasan Komunikasi Bina Kasih, 2008.

Donald Guthrie, Teologi Perjanjian Baru 3, Jakarta: BPK Gunung Mulia, 1998. 
Harun Hadiwijono, Iman Kristen, Jakarta: BPK: Gunung Mulia, 1992.

J.Verkuyl, Aku Percaya, Jakarta: BPK. Gunung Mulia, 1995.

Billy Graham, Berdamai dengan Allah, Jakarta: Yayasan Komunikasi Bina Kasih, 1988.

Suhento Liauw, Doktrin Gereja Alkitabiah, Jakarta: Graphe, 1996

J.l.Ch. Abineno, Garis-garis Besar Hukum Gereja, Jakarta: BPK. Gunung Mulia, 1994.

John Virgil, Kompleksitas Pertumbuhan Gereja, Jakarta: Yayasan Kasih Imanuel, 2001.

David F.Hinson, Sejarah Israel Pada Zaman Alkitab, Jakarta: BKP. Gunung Mulia, 1996.

Th. Van den End, Harta Dalam Bejana, Jakarta: BPK. Gunung Mulia, 1995.

Rick Warren, The Purpose Driven Church, Malang: Gandum Mas, 2005 